\title{
ENVIRONMENTAL RIGHTS FOR THE CANADIAN CITIZEN: A PRESCRIPTION FOR REFORM
}

\author{
R. T. FRANSON*, P. T. BURNS**
}

\begin{abstract}
The environment is a subject that recently has come to the fore of public awareness and has created much interest and controversy. So too has the legal framework which surrounds the environment. The authors discuss the environment and the lack of care taken to preserve the environment when administrative decisions are made. The authors point out that the lack of co-ordination between these administrative tribunals often leaves the environmental consequences of these administrative decisions to their fate. The traditional checks on the administrative process are used primarily to remedy private wrongs and since wrongs to the environment are more public in nature, the requisite standing is usually lacking. Thus, the administrative decisions are insulated from review in this way. Also, most statutes do not require public hearings to be held, thus the public has no input into the decisions. The authors, feeling this path of insulated administrative decisions could lead to dire consequences, have recommended changes involving the legal framework which surrounds the environment. They feel that there should be more public input into the administrative decisions. Legislation should be enacted that would require that environmental impact studies be done before these decisions are made. The authors also recommend that legislation be enacted to give a method of judicial redress for injuries to the environment by creating a right to a safe, clean and healthful environment. The authors suggest that compensation schemes, although necessary, should not be the focal point of environmental redress, but that the legal framework surrounding the environment should be geared to prevention of damage, rather than compensation after the damage has occurred.
\end{abstract}

Canadians have very little access to government decision-makers and few opportunities to seek judicial redress for environmental injuries. Whether access to government agencies and the courts should be expanded, and, if so, how this might be done are the questions addressed in this paper.

\section{THE EXISTING LAWS}

Under existing law, there is no guarantee that governmental decisions affecting the environment will be made with adequate consideration of either the environmental impact of the decision or the available alternatives. ${ }^{1}$ In fact, various factors encourage decision-makers to ignore both.

Decision-making tends to be highly compartmentalized. Small groups of technical experts "solve" technical problems, often without significant input from either the public or experts in other fields. For example, more than ten separate government agencies have powers or responsibilities that could have a major impact on the Fraser River estuary in British Columbia. ${ }^{2}$ The provincial Water

- Bachelor of Engineering Physics, Cornell University, Ithaca, New York; Juris Doctor U.C.L.A. Associate Professor of Law, University of British Columbia.

- LL.B., LL.M., University of Otago, New Zealand. Professor of Law, University of British Columbia.

1 See Matkin, Environmental Policy Formulation: Public Participation and the Role of the Courts, (1973) in Burns, Franson, Matkin \& Slutsky, Environmental Abuse and the Canadian Citizen 38, 80-88 (unpublished manuscript on file at U.B.C. Law Library) [hereinafter cited as Environmental Rights Study]. Since this paper was written, the Honourable Jack Davis, federal Minister of the Environment, has announced that Environmental Impact Assessments will be required on all projects planned, approved or financially supported by the federal government. However, legislation is not planned to give their policy the force of law. See Franson, Blair and Bozzer, The Legal Framework for Water Quality in the Lower Fraser River of British Columbia (Westwater Research Centre, University of British Columbia, 1973.

2 Franson, supra, n. 1. 
Rights Branch allocates the right to divert and use water. The Pollution Control Branch and the federal Department of the Environment both (separately) also regulate the quantity and quality of effluent discharges. The provincial Fish and Wildlife Branch is responsible for habitat protection. The International Pacific Salmon Fisheries Commission is responsible for maintenance of the salmon runs, as is the federal Department of the Environment. The Harbour Commissions (there are two in the Fraser) are responsible for developing the river as a port. The regional districts (there are four) are responsible for land use planning and in some cases for sewage disposal.

Each agency is free to pursue its separate goals. Sometimes, agencies compete with each other for the right to develop areas within their jurisdiction. For example, the Fraser River Harbour Commission is trying to convert the Fraser into a major port at the same time the Harbour authorities responsible for the Vancouver harbour, Nanaimo harbour, Prince Rupert, and Squamish are trying to do the same thing for their ports. Each authority is an independent body. They are not elected and have no responsibilities to the local electorate. They need consult with no one except the federal Department of Transport and they are in competition with one another. The result is that alternatives like reserving some of the sites in an undeveloped condition do not receive fair consideration.

No environmental impact assessment has been prepared, despite the fact that the Fraser estuary is a major stopping place for migrating wildlife and is quite important to the production of food for migrating salmon fry. There is little evidence that fish and wildlife officials have been consulted, and it appears certain that they are not involved in the planning.

The legal structure encourages this kind of behaviour in several ways: by failing to require officials to plan and open their planning to the public; by failing to require the officials to consider the impact of their actions, or the alternatives to them; by fragmenting jurisdiction and giving small groups of experts the power to make decisions that have an impact far beyond their expertise.

Most federal statutes that authorize actions that could have a significant impact on the environment do not require the responsible official to consider the environmental impact that his actions may have. ${ }^{3}$ Participation of the public in decision-making by governmental agencies is usually not required by the legislation. A review of fourteen federal statutes revealed that hearings were required in only two cases. ${ }^{4}$ Other forms of participation are equally missing. Moreover, although most agencies have the power to hold hearings, few actually hold them.

The lack of public participation in decision-making is aggravated by the tendency of legislatures to delegate authority for setting environmental standards to administrative agencies or the Cabinet.5 The really important decisions, those that establish the quality of our environment, are made by civil servants, who are not responsible to the voter, without the benefit of any canvassing of the values held by members of the public.

Opportunities for judicial review of government decisions relating to the environment are non-existent. ${ }^{\circ}$ Many kinds of governmental activity have a large impact on the environment, but most involve administrative discretion that is normally considered to be beyond judicial review. A second bar to effective judicial review is the requirement that the plaintiff have a special interest, or

${ }^{3}$ Matkin, supra, n. 1 at 81.

IId. at 49-53.

SId. at 103-105.

- Id. at 53-61. 
standing, in the subject matter of the litigation. ${ }^{7}$ Since most environmental injuries affect large numbers of people equally, it will normally be very difficult to find an individual with the required standing.

Administrative inaction also poses a problem. In many cases it is expedient for administrative officials to overlook known violations of existing law. ${ }^{8}$ In addition, it is easier to avoid setting pollution standards under existing legislation because this avoids the political controversy that usually results when it becomes clear that a trade-off between widely-held values will be necessary.

The traditional remedy for such inaction is the prerogative writ of mandamus. Two factors bar its effective use by citizens in the environmental area. First, few statutes impose a positive duty on governmental officials. Rather than saying the official shall establish standards for what constitutes a polluted condition, legislatures have chosen to say the official may establish standards. Courts will not direct the performance of a function that is left in the discretion of the administrative official. Second, the plaintiff would normally be unable to show the necessary standing to bring the suit.

Faced with this impenetrable wall around public decision-makers, the individual who feels that his interests are affected by the activities of firms in the private sector may understandably seek to prevent these activities by direct court action against the offending firms. He is immediately met with a host of practical and legal difficulties. Even though he may suffer a real injury he may lack the necessary legal standing to bring an action because his injury is not sufficiently distinguishable from that suffered by the public generally. Or he may be unable to show definite damages because the injury is not direct and obvious.

For example, a fisherman would have a great deal of difficulty showing how much he was personally harmed by a severe fish-kill. His interest is too dependent on other influencing factors, and the productivity of the resource is probably not very heavily affected by one isolated fish-kill, even if it is severe. However, the fisherman feels threatened. Perhaps he is threatened. Many isolated fish-kills can add to a large total impact on the fishery.

Tort law has been largely ineffectual in coping with the problems of environmental abuse.9 This result should surprise no one. The law of torts is primarily concerned in regulating private interests whereas the interest in a safe environment is essentially public in character. ${ }^{10}$

Even within the framework of a public nuisance action, other than where a private individual has suffered special damage, it can hardly be persuasively argued that an effective remedy exists. Relator actions depend initially on the co-operation of public officials and this may or may not be expedient. Perhaps the most positive feature of the tort action at present is its nascent political effect. For example, it may provide the means for persuading polluters or prospective polluters to take remedial action even though both sets of parties

7 Id. at 59.

- See Franson, supra, n. 1 at 33-39; Good, Anti-Pollution Legislation and its Enforcement: An Empirical Study, (1971) 6 U.B.C. L. Rev. 271; Lucas, Legal Techniques for Pollution Control: The Role of the Public, (1971) 6 U.B.C. L. Rev. 167 at 176, 180.

- Burns \& Slutsky, The Effectiveness of Tort Liability as an Ecological Control Device: An Analysis, (1973) Environmental Rights Study 111. See also McLaren, The Common Law Nuisance Actions and the Environmental Battle - Well-Tempered Swords or Broken Reeds, (1972) 10 Osgoode Hall L. J. 505 at 511-520; Estey, Public Nuisance and Standing to Sue, (1972) 10 Osgoode Hall L. J. 569. The characteristics of the environmental management problem are discussed in Franson, The Private Citizen, Technology and Environmental Abuse, (1973) Environmental Rights Study 1.

10 Although, of course, it may intersect with private interests where specific classes of individuals are injured as a result of environmental damage. 
know that in law no cause of action may exist. The fact that an action has been brought may publicize the situation to the disadvantage of the defendant who may not want to prolong the publicity and possible adverse public reaction.

But this is a positive characteristic of limited value. Where a polluter is unaffected by adverse public reaction to his acts and their effects on the environment, then the current law of torts is impotent in the absence of co-operation by public officials ${ }^{11}$ or actual damage sustained by the plaintiff. ${ }^{12}$

\section{WHAT IS WRONG WITH THE EXISTING LAW?}

The existing legal structure severely hampers our ability to reach informed and rational choices. Because authority is delegated so far down the administrative structure and is so compartmentalized, no one is forced to choose between alternatives on a rational basis, especially when dealing with the smaller, more insignificant issues or proposals. The systematic exclusion of the public from the decision-making process isolates the public servant and allows him, even encourages him, to ignore important shifts in societal values and attitudes.

Scientists tell us that most of our activities have a far broader impact on others than had formerly been supposed.13 Seemingly isolated events that appear small and insignificant produce a cumulative effect that is startling. In fact, the evidence suggests that the cumulative effects of small, seemingly unimportant decisions may be more important than the more spectacular politically-visible decisions. Such decisions are made daily by government agencies that have licensing or regulatory powers, free from public scrutiny by virtue of their sheer number and the lack of any information about them.

At the same time, society is changing more rapidly than ever before. ${ }^{14}$ This speed is important. It means that we must be more careful than we have been in the past. Not only do we have the technological power to do more damage to our environment than we have had in the past, but change piles on change so fast that we may find it impossible to correct mistakes by the time we discover them. Every year between 5,000 and 10,000 new chemicals are being introduced into the environment, usually without any analysis having been performed of the effects that these chemicals might have on the environment. ${ }^{15}$ Scientists warn that it is likely that concentrations of a new chemical could build up to dangerous levels before we learn of the danger. ${ }^{16}$

Societal values also seem to be changing. Developments that would have been considered acceptable a few years ago are blocked in heated confrontations. ${ }^{17}$ Thus, it is no longer advisable to operate on the basis of the rules of thumb that the bureaucracy has developed over the years. The means must be found to discover the values that are emerging and to include them in the considerations leading up to the decisions that are made.

As a society, we face the enormous challenge of determining what kind of world we want to live in and of controlling development to give the desired

11 In the case of public nuisance through a relator action.

12 In all other situations.

18 See Franson, supra, n. 9 at 6-13 and authorities cited therein; MacNeill, Environmental Management 7-61 (1971).

14 MacNeill, supra, n. 13 at 46-47; Toffler, Future Shock (1970).

15 Chant, The Nature of the Environmental Problem, an address to the Manitoba Institute of Continuing Legal Education (April, 1973).

16 Id.

${ }^{17}$ See generally, Graham, Reflections on a Planning Failure: Ontario Hydro's Proposed Nanticoke to Pickering Transmission Corridor, a paper presented to the Water Quality Management Decision-making Seminar, University of Victoria (March, 1973). 
result. The legal system which must meet this challenge was molded when it was valid to assume that activities did not have cumulative effects and there was no need to consider complaints that involved small or aesthetic injuries. Its character was completely altered as the administrative state grew and more and more power was transferred from the legislature to government bureaucracies, but it was never modified to take account of this change.

The legal system delegates most power to small unidisciplinary groups of experts, isolates them from the influence of either other experts or the general public, protects their decisions from effective review, and removes any other means of challenging the decisions. It allows us to back into our major decisions.

The following scenario is absolutely typical. A major firm decides to build an industrial plant in an undeveloped area that is beginning to have a recreational importance. It approaches a government agency under an existing subsidy programme for a loan. The loan application is reviewed by people with expertise in financial matters and possibly with expertise in the kind of business being proposed. It is decided to grant the loan. Planning goes ahead, the loan is made, bulldozers appear on the site, and finally conservation organizations learn of the events and react. The protest could take a variety of forms, but in any event is likely to be heated and costly. Because a government loan has been given, the government is likely to feel it must push ahead despite the fact that the recreational potential of the area was never considered in reaching the initial decision.

To follow this path is to invite disaster. We can do better by simply finding ways to ensure that a broader range of alternatives are fairly considered by our decision-makers. No one tactic is likely to suffice, but several used in conjunction do seem to offer promise. Our goals must be to sensitize our decision-makers both to the environmental impact of their actions and the full range of alternatives that are available, and to give the public some real means of participating in the decisions that are made.

Unfortunately, it does not seem likely that innovative use of the legal system will remedy this situation. The limitations imposed by standing requirements, and by the traditional deference given by the courts to administrative tribunals, seem too well established to allow judges any flexibility in meeting the new situation. The judges themselves have shown little inclination to erode these restrictive legal rules. Moreover, the problems inherent in the compartmentalized, unidisciplinary approach to decision-making that characterizes our administrative system seem beyond the reach of courts to change. Thus, we must look to the legislatures for redress.

\section{RECOMMENDATIONS}

\section{Citizen Participation in Decision-Making}

Legislation should be enacted requiring all public agencies engaged in planning for resource management, licensing, or regulatory rule-making to consult with the public periodically either by public hearings or by other equally effective means.

Increased public participation is necessary to inform the public servant concerning the values held by the citizens he serves, how those values are changing, and the full range of alternatives available to society. The case for increased public participation in decision-making has been stated by one of the citizen task forces working under the Man \& Resources Project, and we quote it below: 18

18 Preliminary Report, B.C. Provincial Task Force on Citizen Participation, Man and Resources Project, Canadian Council of Resource and Environment Ministers (April, 1973). 
1. Governments exist through consent of the governed, therefore, legislation affecting a broad segment of the population (e.g., zoning, regional planning, pollution standards) requires the acceptance and support of the public to be effective and enforceable.

2. No single individual, politician, or decision-maker, has the clairvoyance to anticipate and evaluate public opinion on every issue over a four-year period without continuous and comprehensive public input, no matter how great his electoral support.

3. Public attitudes are continually changing over time and with new information, and should therefore, be continually reassessed in making and monitoring decisions.

4. Frequently public opinion has been an important source of information providing the impetus for new legislation (e.g., in pollution control) and as such, should be provided for by statute.

5. Public participation provides alternatives from which decision-makers can choose. Ours is a pluralistic society and often technical reports contain the social/educational/economic biases of their writers and do not take into account the interests and needs of different socio-economic groups.

6. No one knows better than the people themselves where they want to go in the future and what development trends they are willing to support.

7. At present there is no way to estimate the relative worth of intangibles such as 'clean' water or 'pleasant' views; therefore, there is no basis on which planners or decision-makers can make a 'rational' choice. When trade-offs must be made between two intangibles, it is the citizens who must live with the solution who are in the best position to make the choice.

8. When it comes to implementation of policy, decisions which have been reached with maximum public involvement are most likely to have minimum opposition, thus reducing friction, easing implementation, and perhaps avoiding expensive reversal of decisions.

9. Public involvement increases public understanding, knowledge of, and acceptance of necessary technical developments (e.g., sewage treatment plants) in this way acting as an educational system to benefit all parties concerned.

While the reasons for increasing public participation in decision-making may be clear, the means that should be used are far from clear. The available alternatives range from the conventional type of adversary hearing like those held by the National Energy Board ${ }^{19}$ to more open cooperative models. The latter alternative is discussed in a paper by John Graham. ${ }^{20}$ Basically, the agency responsible for a particular planning decision would strike a working committee comprised of representatives of all interest groups that wish to be involved. The working committee would then draw up the plan. Financial assistance would be provided to enable the working committee to hire whatever professional assistance it deemed necessary.

Mr. Graham argues that adjudicative processes (including hearings) are entirely inappropriate for dealing with social issues: ${ }^{21}$

They are costly, time-consuming, cumbersome, and often discriminate against many interests which cannot afford the time or money to participate. In addition, the use of experts and reliance on procedures can be inhibiting to many people. Moreover, the adversary nature of the process encourages the participants to assume the role of the tough-minded lawyer probing the weaknesses in his opponent's argument rather than to be fully responsible individuals who can recognize and be sensitive and empathetic to the values and perceptions of others. The inevitable result of such role-playing is to create tensions and anxieties not only between us but within us as well.

One difficulty with Mr. Graham's argument is that he assumes that people will always be able to reach some suitable agreement. Human experience seems

19 The Board's procedures are discussed in detail in Gibbs, MacFarland and Knowls, A Review of the National Energy Board Policies and Practices and Recent Hearings, (1971) 8 Alta. L. Rev. 523. The advantages and disadvantages of different types of procedures are discussed in Franson, Lucas and Thompson, Legal Problems in the Canadian North (1972); in Arctic Alternatives 313, 325-332 (1973) and in Ask

the People (1973). See also, Arnstein, A Ladder of Citizen Participation, (July, 1969)

J. Amer. Inst. of Planners at 216-224; Peattie, Reflections on Advocacy Planning,

(March, 1968) J. Amer. Inst. of Planners at 80-88.

20 Graham, supra, n. 17.

21 Id. at 23. 
to belie this assumption. However, it does seem clear that there has been very little analysis of the effectiveness of the wide variety of forms of participation available. Perhaps one type of consultation process is appropriate for one kind of decision, and another is better for a different kind of decision. In light of the importance of the subject, high priority should be given to experimentation with the different forms of participation and to empirical research evaluating the effectiveness of each.

For the foregoing reason, we do not recommend any one form of participation to the exclusion of others. In fact, we suggest that different forms be experimented with. But, we very strongly recommend that specific requirements be included in all legislation, and that follow-up studies of the programmes be undertaken. We do not believe that the matter can be left in the hands of the agencies themselves, (who have proven by past performance that they feel threatened by public discussion of their plans and will avoid it at all costs).

It should be noted that the precise form of the hearing or other mechanism may make a very large difference in its effectiveness. For example, whether cross-examination is allowed may affect the willingness of the public to participate. The Pollution Control hearings in British Columbia allow each participant to cross-examine every other participant. The result is a very confusing and complex procedure. It might have been more effective (and believable) for the government to appoint a devil's advocate to challenge the assumptions implicit in the proposals being made.

Whether information is available in advance of the hearings is another crucial determinate of the effectiveness of the process. The British Columbia Pollution Control hearings again afford an example. ${ }^{22}$ No effort is made prior to the hearings to indicate what options are available, what their cost is, and so on. How can anyone expect the public to participate in such a process? If the public are not expected to participate, why are the hearings being held at all? Recent hearings held under the Expropriation Act dealt with the expansion of the Vancouver airport in the same farcical way. No information was made available to the people participating in advance of the hearings, and indeed, no environmental impact studies had ever been prepared. ${ }^{23}$ The result was highly undesirable from all points of view.

One additional bar to effective public participation must be dealt with: the practice of vesting all rule-making powers in the Cabinet. ${ }^{24}$. Regulations are not debated in public as legislation would be, and it is impossible for the Cabinet members to give each new regulation personal consideration because there are too many. The result is that the substance of legislation is formulated by public servants in a process where visibility is very low. ${ }^{25}$

How do you require effective public input in such a scheme? Hearing officers can be appointed to collect reaction, and they can report back to the Cabinet, as is done under the Expropriation Act. ${ }^{28}$ However, those participating

\footnotetext{
22 Franson, supra, n. 1 at 29-33.

23 See Leonard v. Regina, Re A Public Hearing into Objections to the Intended Expropriation for Expansion of the Vancouver International Airport (unreported). The issue attracted a great deal of attention in the local press. The following are representative articles: Sea Islander says Ottawa Skirted the Law, Vancouver Sun, January 11, 1973, at 7; MP's Demand Environmental Study Results on Runway, Vancouver Sun, January 15, 1973 at 11; Airport Expropriation Goes Ahead, The Province, March 3,1973, at 27; No Environmental Study: Airport Goof Disclosed, Vancouver Sun, January 17, 1973, at 1.

24 Matkin, supra, n. 1 at 45-53, 103-104.

$25 \mathrm{Id}$. at 103.

20 R.S.C. 1970, 1st Supp., c. 16, s. 8. The hearing procedures are described in Todd, The Federal Expropriation Act, a Commentary 11-13 (1970).
} 
in such hearings seem to feel that they are not being given a fair chance to affect the decision because they are not able to address the decision-makers directly. ${ }^{27}$ The Vancouver airport expropriation hearings offer a recent example of this phenomenon.

One step that might be taken to alleviate the problem is to allow participants to review and comment on the report the hearing examiner proposes to forward to the decision-maker. This would at least assure. the participants that their point of view had been transmitted to the decision-maker. Unfortunately, however, there is no way of requiring the decision-maker to read and consider the reports in these circumstances.

We believe that far fewer rule-making powers should be vested in the Cabinet. The decisions relating to the substance of such rules are currently all made by the departmental staff. The decisions receive a review by the responsible Minister, and then are transmitted to the Cabinet where they are usually rubber-stamped. If the Cabinet does not have time to give a complete review it is senseless to require the Cabinet to pass on them.

It would be far better to place the responsibility squarely on the department that administers the Act under which the regulations are issued. If this were done, the Minister or officials of the department could sensibly be required to hold hearings. Participants would be less likely to have the feeling that the decision had already been made, and that the hearing report would never be read. The coordinating role of the Cabinet could be preserved by allowing an appeal to the Cabinet by any Minister who felt that his area of responsibility was likely to be adversely affected.

\section{Environmental Impact Assessment and Information Access.}

Legislation must be enacted to assure that information is generated about the impact future projects and programmes will have on the environment, and that that information is disseminated to the public.

Effective public participation in decision-making cannot take place unless adequate information is available about the impact of proposed actions and the alternatives that might be considered. The importance of information generation and access is underscored by the stress placed on the subject at the recent U.N. Conference on the Human Environment. Principle 20, adopted at the conference, states: ${ }^{28}$

[T] he free flow of up-to-date scientific information and transfer of experience must be supported and assisted, to facilitate the solution of environmental problems.

The following recommendations, agreed to by Canada, appear in the background paper for the Conference: ${ }^{29}$

It is recommended that the attention of Governments should be drawn to the need to adopt the following measures:

(a) participation in maintaining the flow of information on the environment by all available means (dissemination of the main data collected by public authorities . . .

(b) the establishment of information machinery...

(c) increased public participation in the main channels of mass information ....

27 Sea Island Hearing Ends, Vancouver Sun, February 26, 1973, at 11; Marchand Unhappy with Law on Airport Expropriations, Vancouver Sun, April 18, 1973, at 17. The point has often concerned the courts when called on to determine the requirements of natural justice. See Local Government Board v. Arlidge [1915] A.C. 120, [1914-15] All E.R. 1 (H.L.); Mehr v. Law Society of Upper Canada [1955] S.C.R. 344, [1955] 2 D.L.R. 289. See also, Reid, Administrative Law and Practice 249-251 (1971).

28 Report of the U.N. Conference on the Human Environment, A/Conf.48/14 (July, 1972).

29 Educational, Institutional, Social and Cultural Aspects of Environmental Problems, Report by the Secretary-General, A/Conf.49/9 at 31. See also, 2 Resources No. 6, (April, 1973) at 32. 
Several of the national and provincial task forces preparing for the coming Man \& Resources conference have also recognized the importance of information access. For example, the task force on citizen participation makes the following recommendations: ${ }^{80}$

It is recommended that the preparation of ecological, social, and resource impact statements be made a condition precedent to the taking of decisions impinging on the environment.

It is further recommended that all information relevant to such decisions and particularly that generated by public funds, be considered as public information, and that the public's right to it be guaranteed.

A Royal Commission study of environmental pollution in the United Kingdom came to similar conclusions. It recommended that government departments involved in control of pollution devise measures to increase the availability and flow of information on the production and disposal of industrial effluents and waste. ${ }^{81}$ It also stressed the importance of assessing the impact of new products, and their associated waste materials, before they are introduced. ${ }^{32}$

Three serious deficiencies can be identified in the way we currently handle information about the environment. First, and most important, information about the environmental impact of proposed projects is either not developed at all, or is developed after the decision has been made to go ahead with the project. The addition of new run-ways at the Vancouver airport and the construction of the MacKenzie highway are but two examples.

A second deficiency is that the means of assessing environmental impacts are not currently at hand. Existing agencies are not interdisciplinary in nature. For example, the National Energy Board will soon decide whether a natural gas pipeline should be built from Prudhoe Bay up the MacKenzie Valley; yet the Energy Board has no expertise on which to judge the environmental effects of such a pipeline..$^{33}$ In fact, most of our public agencies are organized along an unidisciplinary principle because it has traditionally been assumed that issues of resource management can be separated into different specialty areas and can be dealt with most efficiently by specialized agencies. That has not proven to be the case.

The third deficiency that can be identified is the consistent failure of government agencies to make information that is in their possession available to the public. The organization of our civil service emphasizes secrecy rather than disclosure: every federal public servant takes an oath of secrecy ${ }^{34}$ and, by tradition, is bound to protect his Minister and the government from criticism. Moreover, few statutes even hint that the public has any right to information.

(a) Environmental Impact Legislation.

One measure that should be undertaken to remedy these deficiencies is the enactment of legislation requiring all federal departments to prepare an assessment of the environmental and social impact of any actions, projects, or programmes they propose to undertake or approve. Such legislation could be modelled on the U.S. National Environmental Policy Act (NEPA), ${ }^{35}$ with some important modifications.

The National Environmental Policy Act requires all U.S. Federal agencies

so Task Force Report on Citizen Participation, 2 Resources No. 6, (April, 1973) at 3 (Recommendations No. 6 and 7 ).

31 Royal Commission on Environmental Pollution, 2d report: Three Issues in Industrial Pollution, (March, 1972) at 1-3.

32 Id. at 4.

${ }^{33}$ Franson et al., supra, n. 19 at 328.

34 Public Service Employment Act, R.S.C. 1970, c. P-32, Sch. I. See Franson, Governmental Secrecy in Canada, (1973) 2 Nature Canada No. 2 at 31.

3542 U.S.C., s. 4331-47, reproduced in Matkin, supra, n. 1 at 108-110. 
to use an interdisciplinary approach to decision-making, and to further encourage compliance with this policy it requires all agencies to prepare an environmental impact statement, which shall be public, for all major federal actions significantly affecting the quality of the human environment. ${ }^{36}$ The statement is required to include a detailed statement of the following: environmental impact of the proposed action; any adverse environmental effects which could not be avoided; alternatives to the proposed action, including the alternative of not doing anything; the relationship between local short-term uses of the environment and the maintenance and enhancement of long-term productivity; and any irreversible and irretrievable commitments of resources which would be involved in the proposed action. ${ }^{37}$ Copies must be made public and there is an opportunity for comment (although hearings are not required).

Experience under the National Environmental Policy Act indicates that the Act has been successful in two areas. First, it has resulted in the production of many impact statements that contain candid information about the environmental costs of projects being considered. ${ }^{38}$ And second, it seems to have had an impact on the structure of the agencies themselves. ${ }^{30}$ Biologists, botanists, and ecologists are now being hired for the first time by many agencies that previously felt no need for these disciplines. It is in this area that the Act may have its largest impact. By forcing agencies to hire experts from a broad range of disciplines to write their impact statements, the Act is changing the basic organization of the civil service. These new recruits will, in time, have a large impact on the agencies themselves. The process is an educational one. The agencies are slowly being made aware of costs that have not been considered in the past.

A frequently heard criticism of the National Environmental Policy Act has been that it resulted in too much paper work and too much delay. We do not believe this criticism has merit. Delay has often resulted because agencies did not deal with either probable environmental impact or with important alternatives. Such projects should not go forward until this information is available. The environmental aspects of a project should receive no less care and attention than the engineering and economic aspects.

There are a number of respects in which the National Environmental Policy Act model might be improved upon. For example, the National Environmental Policy Act fails to deal with the cumulative effects of seemingly unimportant decisions. As was indicated earlier, the effect of such decisions is often larger than the effects of decisions that receive widespread attention. Canada should provide for impact assessments at the initiation of any new programs, even when the impact will be minor, if the action proposed has the effect of opening new areas to developments that may have a significant impact. For example, an impact assessment should be required when the first subdivision is proposed for an area even though the impact of that subdivision may be very small.

To date there have been two hundred and fifty cases brought under the Act. ${ }^{40}$ Most have dealt with two issues. ${ }^{41}$ First, when must an environmental impact statement be filed? And second, what must be included in such a statement? Litigation of this sort can be avoided in Canada by drawing on the

36 National Environmental Policy Act, 42 U.S.C., s. 4332.

37 Id. at s. $4332(\mathrm{c})$.

${ }^{88}$ Sax, Environmental Law-The U.S. Experience, a paper presented to the Manitoba Institute of Continuing Legal Education (April, 1973).

89 Ingram, Information Channels and Environmental Decision-Making, (1973) 13 Natural Resources Journal 150.

10 Sax, supra, n. 38.

11 Id. See also, Seeley, The National Environmental Policy Act: A Guideline for Compliance (1973) 26 Vand. L. Rev. 295 at 310-313, 321-324. 
experience under the National Environmental Policy Act and specifying, in advance and in greater detail, the procedures to be followed in the preparation of impact assessments.

One issue that has not been resolved by the litigation in the U.S. is whether the National Environmental Policy Act conveys any substantive rights; that is, whether the courts can halt a project that is shown to be unsound by the impact statement that is prepared. ${ }^{42}$ We believe that courts should have that power and, in a later portion of this paper, we recommend the enactment of an Environmental Procedure Act.

While the National Environmental Policy Act has enjoyed some important successes in the United States, it has not accomplished all that it might have. Its most serious deficiency is that it has not facilitated public participation in the decision-making process as much as it should have. There are several reasons. In the first place, hearings are not required on the impact statements, and no other effective means of public comment is provided. In addition, impact statements tend to be drafted after the agency has already made up its mind informally, which is too late to allow for really effective public input. ${ }^{43}$

Canada should seek to assure that effective means of public response and participation exist to complement environmental impact legislation. We have already suggested the need for experimentation in the field of public participation and wish to add here that the production of an environmental and social impact assessment should be viewed as an integral part of the process. Steps must be taken to assure input at an early stage in planning. This may require a two-stage process, including the preparation of preliminary plans sketching the available alternatives and their probable impacts, public debate on these, the preparation of final plans and impact assessments and further public debate.44

\section{(b) Access to Information.}

A second measure that must be taken to assure a freer flow of information about the environment and, thus, to enhance public participation in decisionmaking, is the enactment of legislation guaranteeing Canadians the right to all reports and information produced with public money, as well as any environmental impact assessments the government requires industry to prepare.

Confidentiality does have an important role to play in the Parliamentary process, as an article by Gordon Robertson, Clerk of the Privy Council and Secretary to the Cabinet, points out: ${ }^{45}$

The collective executive that is the heart of our Parliamentary system must have secrecy: it cannot work without it.

Frank and open discussion among Cabinet members would be inhibited if the confidentiality of Cabinet deliberations were not maintained. Confidentiality also encourages senior civil servants to give frank advice to their Ministers. As Robertson points out: ${ }^{48}$

It is the Ministers who decide: the policy is theirs. It does not matter whether it was devised by officials, or whether they argued for it or against it.

42 Sax, supra, n. 39; Comment: The National Environmental Policy Act of 1969: Analysis and Judicial Interpretation, (1973) 25 Baylor L. Rev. 71 at 80.

43 Ingram, supra, n. 39; Kusler and Alston, Environmental Impact Evaluation Procedures: Some Recommendations for Wisconsin 23 (1972).

14 Id. at 4-9, 21-25; Franson et al., supra, n. 19; Task Force Report on Citizen Participation, 2 Resources No. 6, (April, 1973) at 8 (Recommendation No. 1).

4s Robertson, Is the Oath of Secrecy Old Hat?, The Ottawa Journal, June 7, 1971 at 6.

$10 I d$. 
However, practice has diverged widely from the theory of Ministerial responsibility with the development of the administrative state. A great many issues that have significant environmental impacts never reach the Cabinet, but are resolved within the bureaucracy. Other highly significant actions, like the formulation of pollution standards, are formally taken by the Cabinet but receive only perfunctory consideration at that level. The real decision-making power in such situations lies within the upper levels of the public service.

Moreover, the need for confidentiality of Cabinet discussions and recommendations made by senior civil servants does not extend to factual reports, consultant's reports, and so on. The theory of Ministerial responsibility is valid only if the public is well enough informed to hold a Minister responsible for his actions. Thus, the basic data concerning the alternatives available and their impacts must be released to enable the electorate to fulfill its role.

We seem to have too much governmental secrecy in Canada. Our discussions with civil servants indicate two important facts: one, that countless factual documents are languishing in public offices because public servants have no authority to release them and fear that if they do, their careers will be harmed; and two, that this secrecy frustrates and angers the very public servants caught in its trap, impairing their usefulness to all of us.

One civil servant observed publicly that: ${ }^{47}$

The 'Oath of Office and Secrecy' ... which must be sworn by employees of the Federal Government, coupled with the traditional obligation to protect the Minister and the Government from criticism or embarrassing situations, makes it difficult if not sometimes impossible for civil servants to take part in public debates about topics related to their employment .... The level of frustration of those who have knowledge which cannot be made available to the public is reflected somewhat in press leaks, unofficial versions of reports, and resignations.

Legislation is necessary to assure free access to information in Canada. It should establish the right of any Canadian to see information in government files, subject to limited and reasonable restrictions, and should establish the means of securing that information. Government agencies should be required to establish procedures, whereby the public may obtain desired information, and to keep indices of its rules, administrative and procedural manuals, and any factual studies that have been performed concerning matters within its jurisdiction. An independent commission should be created to hear appeals by persons who are aggrieved by refusals of government agencies to produce requested papers, to establish guidelines for the production of papers, the maintenance of indices, and the establishment of procedures to be followed in dealing with requests for information.

In drafting such legislation, great care must be taken to define and limit the classes of papers that will be exempt from production since experience has shown that exemptions may easily be abused; ${ }^{48}$ however, in the last analysis the independent commission will provide the best protection against abuse.

${ }^{47}$ Thompson, The Scientist, the Civil Servant and Public Participation, an unpublished paper presented to the workshop on Canadian law and the environment, Banff, Alberta, (March, 1972). The author makes the same point in an abbreviated form in the published proceedings of the conference-Ask the People 4-5 (1973). See also, McKeown, Leaks in the Ship of State, 23 Weekend Magazine, No. 19, May 12,1973 , at 20-22.

48 See Katz, The Games Bureaucrats Play: Hide and Seek Under the Freedom of Information Act, (1970) 48 Texas L. Rev. 1261. Useful references on the topic of information access include Fortier (Chairman, Task Force on Government Information) To Know and be Known (1969); Gibson, Freedom of Information and Canadian Welfare Law, (1973) 2 Bull. Can. Weîfare Law 6 at 15-16; Rowat, How Much Administrative Secrecy? (1965) 31 Can. J. Of Econ. and Pol. Sci. 479; Knight, The Administrative Secrecy and Ministerial Responsibility, (1966) 32 Can. J. of Econ. and Pol. Sci. 77; Rowat, The Administrative Secrecy and Responsibility: $A$ Reply, (1966) 32 Can. J. of Econ. and Pol. Sci. 84. 


\section{Financial Assistance for Citizen Groups.}

The legislation suggested above should greatly improve the quality of public participation in environmental decision-making. One more important feature is needed: private citizen groups need financial support to enable them to analyze the impact assessment that will be available.

The data and analysis contained in such reports will be highly sophisticated. To understand it and respond to it, the average citizen will need the assistance of the professional.

We are not suggesting that citizen groups cannot bring fresh viewpoints forward without such assistance, or that impact assessments are the exclusive domain of the professional. Far from it. What we suggest is that more benefits will be derived at less cost if such assistance is provided.

If as little as one-tenth of one percent of the cost of a project were made available, the amount of misinformed controversy surrounding the project would be reduced substantially. An independent commissioner might be appointed to consider applications from organizations wishing to use the funds for analysis of the project. We do not wish to suggest the form that should be used to oversee such a fund, but we do urge that such funds should be created on an experimental basis and that the performance under them should be monitored with a view to developing a workable method of encouraging sound analysis of environmental issues by the public.

\section{An Environmental Procedure Act.}

Legislation should be enacted, by the provincial and federal governments, recognizing the right of Canadians to a clean, healthful, and aesthetically pleasing environment and providing an effective means of judicial redress for existing or threatened injuries to the environment.

The right to a safe and clean environment is widely recognized. It is explicitly recognized in the principles adopted at the United Nations Conference on the Human Environment, to which Canada subscribes." ${ }^{49}$ In Blackstone's time, it was recognized that: ${ }^{50}$

There are some few things, which notwithstanding the general introduction and continuance of property, must still unavoidably remain in common . . . Such (among others) are the elements of light, air, and water.

As one modern commentator has observed: ${ }^{51}$

[I]f these things are common to all, then the citizen does have a 'right', which is different and separate from the right he enjoys if his property receives the natural benefit of these things.

Although the right exists, the means of enforcing it has not been vested in the private individual. ${ }^{52}$ It has been vested in the state. Unfortunately, the state has not been vigorous in its efforts to protect these common rights, probably because the safest course, politically, is usually not to raise controversial issues, but to allow them to lie dormant.

10 A number of the principles adopted at the Stockholm Conference directly recognize this right. See Report of the United Nations Conference on the Human Environment, $A / C o n f .48 / 14$ at $4-7$.

so II Blackstone's Commentaries 14, as quoted by McRuer C.J.H.C., in McKie et al. v. The K.V.P. Co. [1948] 3 D.L.R. 201 at 210 (Ont.H.C.).

51 Fraser, The Role of the Common Law: Its Strengths and Weaknesses in Dealing with Environmental Problems, a paper presented to the Manitoba Institute of Continuing Legal Education, (April, 1973).

$82 \mathrm{We}$ are indebted to Mr. Fraser for the argument being presented here. 
The most fundamental procedural bars to access to the courts are clearly the limit imposed on class actions being brought ${ }^{33}$ and the requirement that a plaintiff in a public nuisance action show a special injury." For example, very often the only persons who want to pursue a pollution case are those who either cannot afford to do so as individuals or who have no material interest of their own injured as a result of the polluter's acts. The basic question is whether or not interests beyond those immediately injured by a prospective defendant should be recognized as worthy of legal protection. Phrasing it another way: should there be any procedural bar, based on disaffection of personal material interest, to a court hearing an application regarding environmental diminution? ${ }^{55}$ The wider interest worthy of legal protection is very simply that of having a safe environment.

It is difficult to see what justification can be raised in favour of a procedural bar to judicial hearings concerning invasion of this interest, other than the one of administrative convenience. It has been argued that abolition of the standing requirement would cause the courts to be inundated by vexatious and unjustified actions. In the United States, however, where the standing requirement has been largely swept aside, this does not appear to be the case. ${ }^{56}$ In any event, the power to award costs against an unsuccessful litigant is usually a sufficient deterrent to such actions.

Another argument often advanced for not opening the courts further to environmental litigation concerns the capacity of the court to judge complex questions. It is asserted that courts cannot be expected to resolve the sorts of disputes that arise in the environmental field because of the complex scientific data that is required and because most of the issues involve more than two parties.

The complexity of environmental issues may require the creation of an administrative structure within governments to deal with it. It does not, however, require us to erect purely procedural barriers to judicial consideration of environmental problems. It must be remembered that the requirement of standing and the limitations on class actions have nothing to do with the merits of a dispute, or with its technical complexity.

Moreover, the courts can deal with disputes that are complex both in the technical issues they present and the number of interests affected. Contract litigation involving a major hydro development certainly involves such complexity, as do patent and labour relations litigation. Moreover, the capacity of courts to deal with environmental issues has been directly demonstrated in Professor Sax's studies of environmental litigation. ${ }^{57}$

${ }^{53}$ Burns \& Slutsky, supra, n. 9 at 113-116. See Markt and Co. v. Knight Steamship Co. [1910] 2 K.B. 1021 at 1035 (C.A.).

54 See Matkin, supra, n. 1 at 59; Burns and Slutsky, supra, n. 9 at 132-142; Estey, supra, n. 9 .

65 The "interest" involved here would be that of having a safe environment. It has been described as a synthesized analogy to the private interest in quiet use and enjoyment of land, the interest in the proper use of land by government for the public trust, and the interest in the proper functioning of government agencies. Pearce, The Michigan Environmental Protection Act, (1972) 4 J. of Law Reform 121.

${ }^{56}$ See Eddy, Locus Standi and Environmental Control, (1971) 6 U.B.C. L. Rev. 193; Sax, Michigan's Environmental Protection Act of 1970: A Progress Report, (1972) 70 Mich. L. Rev. 1003. A later paper by Professor Sax, supra, n. 38, indicates that current experience in Michigan still conforms to that reported in his 1972 article.

s7 Id. See also, Sax, Defending the Environment (1971). 
Of the various ways in which the interest in a safe environment may be established and protected, the Michigan Environmental Protection Act ${ }^{58}$ (Mich. EPA) is the most innovative and effective, and we recommend it as a model for a Canadian Environmental Procedure Act. The Mich. EPA allows any person or corporation to maintain an action for declaratory or equitable relief where it is alleged that the defendant has polluted, or is likely to pollute, impair or destroy the air, water or other natural resources or the public trust therein. Suit may be brought against private developers or government departments.

The Mich. EPA provides for class actions as well as personal actions and does not require the plaintiff to establish injury to his material interests in order to be permitted to bring the action. In many areas, standards relating, for example, to pollution levels permissible will already be in existence. The Act requires the circuit court to determine the validity, applicability and reasonableness of such standards when granting relief under it, and, if the court regards a standard to be deficient, direct the adoption of proper standards.

The Act also creates a type of reverse onus clause whereby, once a prima facie case has been made by the plaintiff, the burden of disproof is thrown on the defendant. The defendant can satisfy the burden cast on him by either one or both of two methods: (1) He can argue the substantive issue and rebut the allegation that he has polluted, or is likely to pollute, impair or destroy the air, water or other resources or the public trust therein; (2) He can also raise the affirmative defence that "there is no feasible and prudent alternative to his conduct and that such conduct is consistent with the promotion of the public health, safety and welfare in light of the state's paramount concern for the protection of its natural resources from pollution, impairment or destruction".50

The Act authorizes the court to deal with the issues itself or to appoint a master or referee to take testimony and report his findings to the court. Such a person is to be technically qualified and disinterested. This has the advantage of enabling the court to have access to independent evaluation of difficult scientific evidence that may be critical in determining the outcome of the case. The court may also remit the hearing to any available administrative proceedings to determine the legality of the defendant's actions. The court retains jurisdiction and proceeds when the determination is made.

The powers of the court in granting relief are considerable. It can grant permanent or temporary equitable relief and impose the conditions on the defendant felt necessary to achieve the enactment's objectives. When the proceedings are complete, the court is required to "adjudicate the impact of the defendant's conduct on the air, water or other natural resources and on the public trust therein .... ".60

Where administrative, licensing or other proceedings, or judicial review thereof, relating to environmental matters take place, they cannot authorize or approve conduct that does, or is likely to, pollute, impair or destroy the air, water or other natural resources or the public trust therein, so long as there is a feasible and prudent alternative consistent with the reasonable requirements of the public health, safety and welfare.

The equitable injunctive process provided in the bill is likely to be of extreme significance. The remedy of damages may be entirely inappropriate to

58 Mich. Comp. Laws Ann., ss. 691.1201-691.1207 (Supp. 1972). The full text is printed as Appendix A to Professor Matkin's study, supru, n. 1 at 106-107.

59 Michigan Environmental Protection Act, s. 3(1), Mich. Comp. Laws Ann., s. 691.1203 (1) (Supp. 1972).

oo Michigan Environmental Protection Act, s. 4(3), Mich. Comp. I.aws Ann., s. 691.1204 (3) (Supp. 1972). 
environmental abuse. Damages are designed to compensate for loss suffered, but the most effective solution is likely to be the prevention of the environmental deterioration from occurring at all.

It follows that, given an expanded area of application, an injunction quia timet could be the most critical weapon in the environmentalist's arsenal against environmental deterioration. It could be issued to direct the doing or not doing of something in anticipation of the future injury concerned. In short, prevention is more desirable than compensation. It may be possible to compensate people for loss of economic advantage or opportunity through environmental deterioration but compensation is irrelevant in the context of complete destruction of a species of wildlife on which nobody relied for economic support.

At present, its role is limited to cases where the applicant can show his proprietary rights are being, or are about to be, wrongfully interfered with by the defendant. For injunctions to play any real role in environmental protection, their application will have to be extended beyond those cases where the applicant's interests are affected or threatened by the defendant, as is provided for in the Michigan legislation.

The Michigan Environmental Protection Act provides a forum alternative to the legislative or administrative avenues which, although inherently flexible, are bound to develop judicial standards against which existing and prospective action may be gauged. Sax, in his evaluation of the first sixteen months of its operation, reveals that only thirty-six cases were filed over that period, of which thirteen had been decided. ${ }^{61}$ He concluded that although somewhat inert, government and industry can and do respond to pressures for reform, ${ }^{62}$ that regulatory agencies are "liberated" from political pressure when named as defendants in suits under the Act, ${ }^{68}$ and that informed common-sense is the essence of resolving environmental disputes. ${ }^{64}$ But the enactment's greatest value has proven to be its ability to reinforce in ordinary people the confidence that they can "have their day in court" when environmental safety is threatened. ${ }^{65}$

One of the most significant features of the Act is that it allows courts to overrule agency decisions on the merits. For example, the courts are expressly given the power to question the adequacy of environmental quality standards that have been established. ${ }^{\circ}$ This provision is particularly valuable because it allows the courts to counteract the tendency, exhibited in any regulatory scheme, for regulators to be co-opted by the industry being regulated.

Canadian administrative lawyers may be expected to express concern over the wisdom of including such provisions in Canadian legislation. The discretionary

61 Sax, supra, n. 56 at 1007. In his more recent unpublished paper, supra, n. 38, Professor Sax indicated that in the first thirty months since enactment of the Michigan Environmental Protection Act, 55 court cases have been started involving diverse issues. Experience clearly shows that the courts have not been inundated. An average of two cases per month have been started. The median time from start to the end of the law suit has been about five months (in other words a great many cases were settled). Twenty per cent of the cases have gone to full trial with a median time of eight months. In a few cases there have been delays of over one year, but in each of these cases no project was being held up pending outcome of the law suit.

62 Sax, supra, n. 56 at 1009, 1080-1081.

68 Id. at 1080-1081.

04 He feels that reliance on "experts" has been found very often to be misplaced.

65 The Act contains two provisions designed to protect potential defendants from abuse: the power to require the plaintiff to post a surety bond or cash, not exceeding $\$ 500$, when his ability to pay costs is in doubt; and the power to aportion costs to the parties "if the interests of justice require".

${ }^{66}$ Michigan Environmental Protection Act, s. 2(2); Mich. Comp. Laws Ann., s. 691.1202 (2) (Supp. 1972). 
powers of government departments and tribunals have traditionally been protected here. But is it not time to ask whether this faith in the administrative process has been misplaced? Agency co-option is a demonstrated fact. ${ }^{67}$ And many environmental management decisions are made by default because various departments of government are reluctant to raise potentially controversial issues.

In our view, the time has come to give Canadians the power to take the initiative themselves. To be effective, legislation must give the courts the power to decide disputes on the merits. Our traditional forms of action, which limit judicial review to the regularity of administrative procedures, are wasteful and ineffective. They are wasteful because they result in sending the issue back to the agency for a fresh determination. They are ineffective because the agencies simply observe the procedural requirements and make the same decision all over again.

The effect of such review is not to displace the will of the elected representatives of the people, but to require that the elected representatives turn their mind to the issues. It should be emphasized that such legislation would not remove the paramount power of Parliament to undertake developments it feels are in the public interest. If the legislatures wish a project to go forward, it is always easy to overrule court orders halting the project directly. ${ }^{68}$ An Environmental Procedure Act would have the advantage of forcing the legislature to consider such projects explicitly, rather than allowing significant environmental damage to occur because of governmental inaction.

One final issue must be dealt with. It can be argued, persuasively, that issues of environmental management can be resolved in a non-adversary setting better than they can be resolved in an adversary setting. Some would conclude that, therefore, further access to the courts should not be provided.

We do not assert that the courts should become the principal forum in which environmental issues are determined. Certainly, such issues are usually settled better by agreement among those affected, or by the administrative agencies that now deal extensively with the problems, than they are by litigation. The same can be said of any area of the law. Unfortunately, reasonable people can not always reach agreement without assistance, and administrative agencies do have a kind of inertia that often prevents them from considering all the alternatives that should be considered. The role the courts can play, and should be allowed to play, is to give the private individual a forum where he can take the initiative and present a different perspective on environmental problems than is currently offered by existing agencies.

We recognize that constitutional limitation may prevent the federal government from enacting legislation that accomplishes all the objectives set forth above. The concerns expressed in this paper result, in part, from activities constitutionally controlled by the provinces. We submit though, that where it is constitutionally permissible, appropriate legislation should be enacted by the Government of Canada empowering the Federal Court to examine and determine

67 The classic demonstration of co-option is Selznick, TVA and the Grassroots (1949). For more recent statements of the problem see Bernstein, Independent Regulatory Agencies: A Perspective on Their Reform (1972) 400 ANNALS Amer. Acad. Pol. \& Soc. Sci. 14 at 23-24; Leone, Public Interest Advocacy and the Regulatory Process 400 ANNALS Amer. Acad. Pol. \& Soc. Sci. at 47, 49-51. See also, Jaffe, The Effective Limits of the Administrative Process: A Re-evaluation, (1954) 67 Harv. L. Rev. 1105 at 1113; Seidman, Politics, Position and Power: The Dynamics of Federal Organization 224 (1970).

${ }^{68}$ E.g., the K.V.P. Co. Limited Act, S.O. 1950, c. 33, dissolving the injunction awarded in McKie v. K.V.P. Co. [1948] O.R. 398, [1948] 3 D.L.R. 201 (H.C.); aff'd [1949] 1 D.L.R. 39 (C.A.); aff'd [1949] S.C.R. 698. 
environmental matters along the lines of the Michigan Environmental Protection Act. In addition, the provinces should be encouraged to enact parallel legislation.

\section{Compensation Schemes.}

Statutory compensation schemes, as distinct from causes of action arising under statute, are a phenomenon of relatively recent origin. But they are becoming increasingly widespread in their creation by both the federal and provincial governments. They may be comprehensive, along the lines of a "state-insurance" model like workmen's compensation, unemployment insurance, social assistance and crime-victim indemnification, or they may be focussed on compensation for a particular variety of injury like maritime pollution, pesticide residue damage and nuclear damage. ${ }^{60}$

Compensation schemes tend to arise on a purely ad hoc basis and are limited in their application. As an alternative to legal action, they may be desirable in enabling narrow classes of claimants to apply for compensation where the common law may not recognize the legitimacy of the claim on the ground of an absence of standing or because the cause of action does not fall under any existing cause of action. But the fundamental weakness of the compensation scheme approach is that it is entirely oriented towards reparation. That is, it recognizes the harm has occurred but sets up no structure to prevent recurrence. It usually does not provide for the means to prevent the injury from occurring. ${ }^{70}$

In principle, it is suggested that the law should be primarily concerned with granting the means to prevent environmental injury. Compensation schemes tend to distort that emphasis and focus on reparation. Also, reparation, as an exclusive goal, may be desirable only when viewed from the perspective of personal loss. How is society to be reparated for the destruction of its wildlife or the increasing toxicity of its life support system? At the point in time when society can demonstrate its damage, it will be no longer able to function.

On the other hand, it must be recognized that economic growth or even stability will necessitate environmental impact. In many cases, the impact will be outweighed by the goals achieved. Assuming that a considered view has been taken of all the incidents of such an impact, and the goal is still regarded as the more desirable, then compensation schemes assume a more significant role. They can provide an accessible and administratively convenient system of resolving reparation claims. But it is suggested that these should be structured in such a way as to relate to those situations that occur only after the opportunity to prevent the injury from occurring at all has been properly exhausted.

\section{CONCLUSIONS}

In this paper, we have recommended that legislation be enacted by both governmental levels:

(1) Giving individuals greater rights to participate in environmental decisionmaking than they now enjoy;

60 For a description of these three classes, see Matkin, supra, n. 1 at 95-102.

70 In theory, reparation schemes prevent injury by forcing those responsible for injuries to pay for them. For example, under most Workmen's Compensation schemes, the employer's contribution is determined by the loss experience of his plant. Those who have higher loss rates must pay more; thus, it is in the employer's interest to make his operations reasonably safe. It is difficult to see how such a scheme could contribute to environmental control. Since it is often impossible to determine, with accuracy, which operations have caused environmental degradation, it would be impossible to devise a rate structure for a compensation plan that would have the desired effect. Moreover, many forms of environmental damage simply cannot be evaluated in monetary terms. 
(2) Requiring government departments and tribunals to prepare environmental impact assessments whenever they propose to adopt or approve a course of conduct that may have a substantial impact on the environment;

(3) Guaranteeing individuals open access to all data and reports prepared at government expense, or required to be prepared before government approval can be given a project;

(4) Providing a financial support for citizen organizations that wish to participate in environmental decision-making; and

(5) Guaranteeing individuals access to the courts to protect their rights to a clean and healthful environment.

None of these suggested actions is seen as a panacea for our environmental ills. They are intended merely to help focus society's attention on the environmental costs of its actions by giving individual citizens information about the impact proposed actions will have on the things they value, and the means of expressing their views and values in forums where they will be heard. Other complementary measures, like public education programs and use of the mass media, have as large a role to play.

Our decisions must, in the main; continue to be made by our elected officials and public servants. The changes recommended here are intended to enhance their ability to reach wise decisions by eliminating existing barriers to communication. 